\title{
Analysis of the Role of IT Governance on ERP Systems Implementation
}

Soukaina Elhasnaoui, ENSEM, Morocco

\begin{abstract}
An ERP (enterprise resource planning) is an information system that makes it possible to manage and monitor on a daily basis all the information and operational services of a company. It is able to effectively reduce the cost of products, improve customer service experience, and increase business competitiveness. However, the implementation rate of the ERP system is much lower than originally planned, and many companies have not achieved the intended objectives. This situation is due to many factors (high implementation costs, technical complexity, lack of well-trained employees, lack of incentive mechanisms, etc.), but the key element is the separation of relations between the ERP system and enterprise strategy, organizational structure, and business processes. The purpose of this paper is to examine the role of IT governance in achieving ERP performance with a focus on the implementation phase.
\end{abstract}

\section{KEYWORDS}

Enterprise Resource Planning, Implementation, IT Governance

\section{INTRODUCTION}

ERP systems have become vital strategic tools in today's business world. An ERP system allows an organization to integrate all essential business processes in order to increase efficiency and maintain a competitive position (Nah, 2001). ERP initially covered all current transactions within an organization. However, it was later extended to external customers and suppliers (Turban, 2006). However, without a successful implementation of the system, the expected benefits of increased productivity and competitive advantage would not be forthcoming. One of the main problems in implementing the ERP system is aligning the relationship between the ERP system and the enterprise policy, organizational structure, business processes and business information (Gattiker, 2004), (Haines, 2004), (Nah, 2003), (Schimizu, 2004).

In recent years, IT governance has caught the attention of businesses. To enable companies to effectively integrate IT governance and business management, the Information Systems Audit and Control (ISACA) association published COBIT 5 in 2012. It provided a general framework of principles, practices and tools. Analysis and application models of IT governance applicable to managers, auditors and IT users, to help senior management and the IT department to strengthen the trust of individuals or groups related to the IT asset of advantage. The adoption of IT governance in an ERP environment by a company can reduce the risks and the costs of response because its information system is facing a change.

Risk management and control are considered essential in IT governance. Effective risk management can increase business opportunities and reduce potential losses. It must also achieve 
the objectives of the organization. The role played by shareholders in risk management is also one of the important factors for the success of IT projects (De Bakker, 2010).

The purpose of this study is to evaluate the impact of IT governance on improving the performance of ERP systems.

From the literature review in this study, we study the importance of IT governance for ERP systems.

\section{LITERATURE REVIEW}

\subsection{ERP Performance}

The key performance indicators for ERP systems are: quality of the system, quality of information, use of the integrated management system, user satisfaction, individual and organizational impact (Tsai, 2015). Organizations have ERP systems to improve their operational performance and profitability (Ruivo, 2014).

As a result, IT is increasingly seen as a tool to support management activities that involve making decisions about the complexity of organizational problems. The ERP system requires a large IT investment and its efficiency is complicated to examine (Carvalho, 2017). Organizations need to focus more on pre-trial IT governance to improve the performance of enterprise information management (ERP) software packages. IT governance will be built through decision-making, goal-setting and organizational capacity building for targeted goals and objectives (Chang, 2016).

\subsection{Implementation of ERP Systems}

The ERP performance occurs in the post-implementation sentence. As a result, the post-implementation review process needs to be well managed (Motwani, 2010). The implementation of ERP can be considered a radical novelty and requires organizational change (Van Grembergen, 2005). The implementation of ERP is successful when the ERP becomes more complex to maintain its functioning after implementation (Chang, 2016). The subsequent implementation of ERP systems includes: an audit; ERP documentation and advertising success; success of the correspondence; success of the process; success of the interaction; expected success and comparative analysis (Devos, 2012).

\subsection{Objectives and Performance of IT Governance}

(Tsai, 2015) proposed a model using the Balanced Scorecard to measure the IT governance indicator. It has four perspectives. (1) Perspective of contribution of the company. It refers to the maximum value created by an IT company for a company. This dimension can be measured by strategic alignment, value creation and risk management; (2) Stakeholders' point of view. This means that IT must be able to meet the expectations of internal and external stakeholders; (3) operational excellence perspective. It refers to the effectiveness and sustainability of IT governance. (4) Future perspective. It refers to the establishment of distribution channels for subsequent IT governance.

ISACA released COBIT as a core framework for IT governance in 2000. COBIT includes five dimensions: strategic alignment, value creation, resource management, risk management, and performance measurement. Later, ISACA published COBIT 5 in 2012 to guide businesses in connecting IT governance to management. COBIT 5 provides globally applicable principles, practices, tools, and analytical models as a framework and best practices for IT managers, auditors, and IT users. It assists business and IT managers in building the confidence of individuals or groups in the company's IT assets and maximizing their benefits.

\subsection{IT Governance and ERP Systems}

IT governance and ERP systems become inseparable in deciding business process standards, regulations, and requirements. As a result, organizations with good IT governance have more effective 
ERP investments (elhasnaoui, 2014). IT governance has been described and must be implemented to achieve business objectives, reduce associated risks and achieve IT control (elhasnaoui, 2016).

\subsection{IT Governance Framework}

IT value depends on a variety of business factors, such as: size, structure, knowledge, skills, culture, and abilities (elhasnaoui, 2017). Better integration of IT governance involves risk aspects such as: people, processes, strategy and tools (De Smet, 2016). IT governance is attributed as processes, structures and relational mechanisms of decision support (Rubino, M., 2014). IT governance gives approval to an IT manager who focuses on the essential requirements: cost control, risk reduction, and the value of the information system (Tsai, 2015).

\section{IT GOVERNANCE FRAMEWORK FOR THE IMPLEMENTATION OF THE ERP SYSTEM}

Based on the connotation of IT governance (Peter Well,2004) and the condition of the ERP system, we propose a framework of IT governance for the implementation of the ERP system illustrated in Figure 1. As shown in Figure 1, these four components have shaped a closed cycle of ERP implementation.

Figure 1. An IT governance framework of ERP system implementation

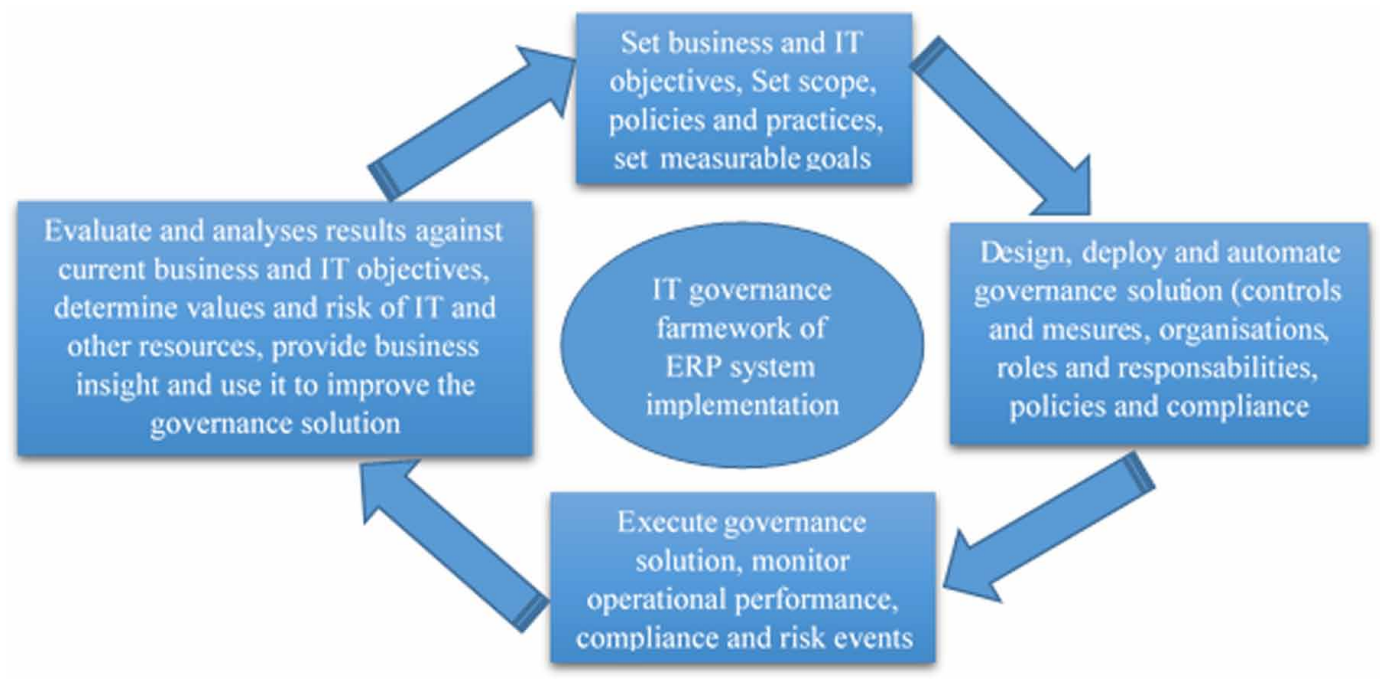

\subsection{Set Business and IT Objectives, Define Scope, Policies and Practices, Set Measurable Goals}

Typically, the ERP system strategy that helps the company accomplish its missions includes the following:

- The ERP system aligns with the company's operations, enables the business and maximizes its benefits.

- $\quad$ TT resources are integrated and used responsibly. 


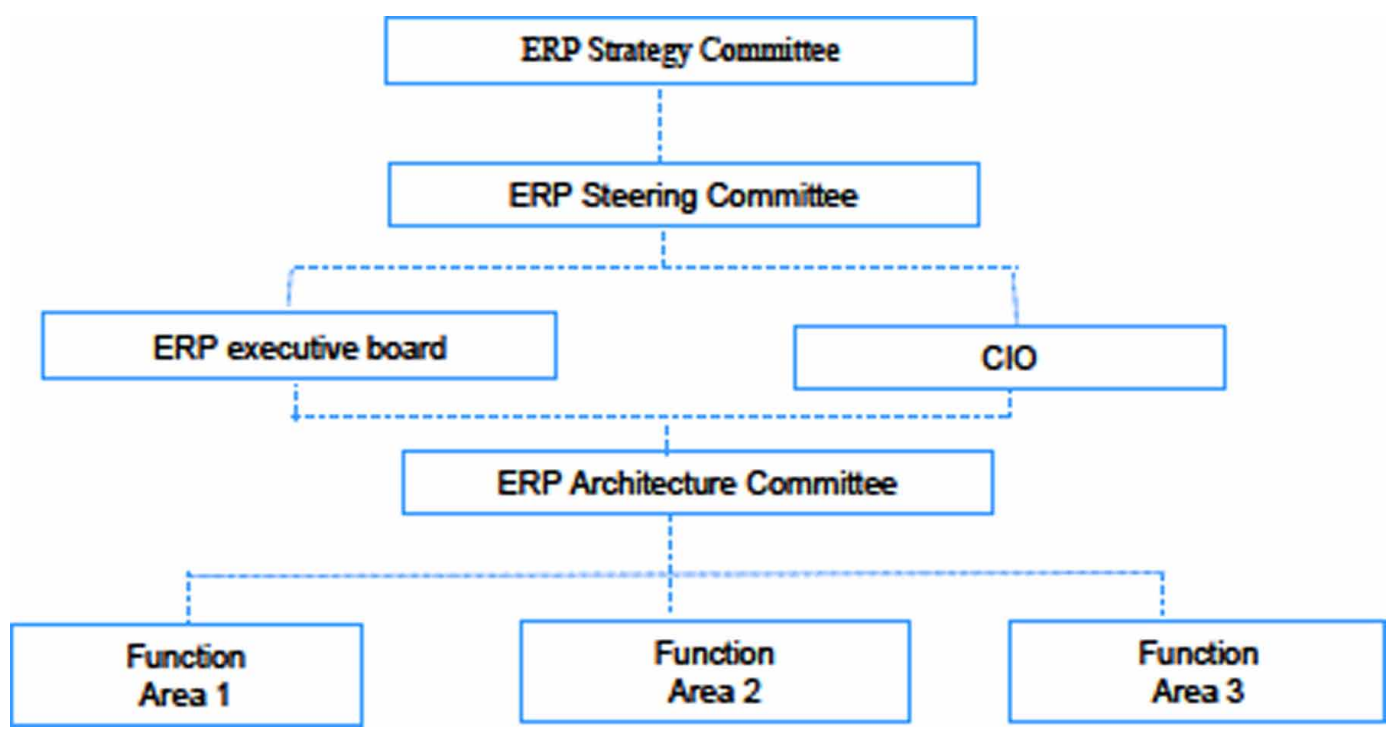

- Risks related to the implementation of the ERP system are managed appropriately. To implement the enterprise strategy, there are four important tactical concepts: ERP principles, business process customization.

\subsection{Design, Deploy and Automate a Governance Solution (Controls and Measures, Organizations, Roles and Responsibilities, Policies and Compliance)}

Figure 2 illustrates the hierarchical structure of the ERP implementation organization, as well as the responsibility of each organization (Zhuang Chen, 2008).

- $\quad$ ERP Strategy Committee

- Aligning IT with businesses

- IT contribution to the company

- exposure and control of IT risk

- Optimization of IT costs

- Achievement of strategic IT objectives

- $\quad$ ERP Steering Committee

- Decide on the centralization or decentralization of IT and the assignment of responsibilities

- makes recommendations for strategic plans

- approves the IT architecture

- Review and approve plans, budgets, priorities and milestones.

- Monitors major projects and delivery performance

- ERP Executive Board

- Allocate the commercial resources needed to ensure efficiency.

- IT governance of ERP projects and operations.

- Act as a sponsor for the main ERP modules.

- Check the application level of the ERP system.

- Identify and acquire the new requirements of the ERP system.

- Chief Information Officer

- Clarify and demonstrate the value of the ERP system. 
- Perform daily management and verification of the development and application of the ERP system.

- Implement ERP standards and associated policies.

- $\quad$ ERP Architecture Committee

- Identify strategic technologies and standards application to support the ERP system.

- Consult / advise on architectural application guidelines.

- Function Areas

- Propose the module related to the functional area.

- Use the ERP software with competence.

\subsection{Execute the Governance Solution, Monitor Operational Performance, Compliance and Risk}

The ERP implementation governance mechanism assigns decision-making responsibilities to key decisions to implement the ERP system.

- Strategic Planning Process

- Strategic: Long-term management (3-5 years) takes into account organizational objectives, regulations (and technical advances).

- Tactic: A one-year plan allows the organization to achieve its strategic goal.

- Operational: detailed or technical plans.

- Strategic Security Planning

- Risk Management - Laws.

- Governance - Politics.

- Organizational security.

- Classification of data.

- Audit - Risk Analysis.

- Continuity of activity.

- Development of metrics.

- Response to the incident.

- Physical security.

- Internet security.

- Compliance policy.

- Use of metrics.

3.4 Evaluates and Analyzes Results Against Current Business and IT Objectives, Determines the Values and Risks of IT and Other Resources, Provides Information about the Business and Uses it to Improve the Governance Solution

\section{KPI Measurement Categories}

- Performance measurement: what are the indicators of a good IT performance?

- IT control profile: How can we measure the effectiveness of our controls?

- Awareness: What are the risks of not achieving our goals?

- Comparative analysis: what is our performance compared to others and standards?

Balanced Scorecard

The Balanced Scorecard is a good tool because ERP implementation KPI measurements are shown in Figure 3. 


\section{Financial Goals \\ How should we appear to stockholder? \\ Vision: \\ Metrics: \\ Performance:}

Customer Goals

How should we appear to our customer?

Vision:

Metrics:

Performance:
Internal Business Process

What business processes should we excel at?

Vision:

\section{Metrics:}

Performance:

Learning and Growth Goals

How will we improve

internally?

Vision:

Metrics:

Performance:
ensure a good return on investment of ERP systems
commercial investments
Manage commercial risks related to ERP
improve corporate governance and transparency

Customer Perspective

Improve customer orientation and service.

Offer competitive products and services.

Establish continuity and availability of service.

Create agility to meet the changing demands of your business.

Achieve cost optimization of service delivery.

Obtain reliable and useful information for strategic decision-making.

Internal Perspective

- Improve and maintain the functionality of business processes.

- Reduction of process costs.

- Comply with laws, regulations and external contracts.

- Ensure compliance with internal policies.

- Manage business change.

- Improve and maintain operational and staff productivity.

Learning and Growth Goals

- Manage product and business innovation.

- Acquire and maintain qualified and motivated people. 


\section{CONCLUSION}

Establishing a good IT governance framework for implementing the ERP system is critical to the success of its implementation. The document proposes a framework of IT governance for the implementation of the ERP system. "Set business and IT objectives, define scope, policies and practices, set measurable goals", and "Evaluates and analyzes results against current business and IT objectives", are two main focuses for companies that are ready to implement an ERP system. 


\section{REFERENCES}

Carvalho, H. L., \& Guerrini, F. M. (2017). Reference model for implementing ERP systems: An analytical innovation networks perspective. Production Planning and Control, 1-14.

Chang, S. I., Wang, T., \& Li, H. J. (2016). A study of ITG mechanism in postimplementation phase of an ERP system. Proceedings of the 2016 Pacific Asia Conference on Information Systems.

Chang, S. I., Wang, T., \& Li, H. J. (2016). A study of ITG mechanism in postimplementation phase of an ERP system. Proceedings of the 2016 Pacific Asia Conference on Information Systems.

Chen, Z., \& Wang, T. (2008). An IT Governance Framework of ERP System Implementation for Chinese Enterprises. Proceedings of the 7th World Congress on Intelligent Control and Automation, 4929-49.

De Bakker, K., Boonstra, A., \& Wortmann, H. (2010). Does Risk Management Contribute to IT Project Success? A Meta-Analysis of Empirical Evidence. International Journal of Project Management, 28(5), 493-503. doi:10.1016/j.ijproman.2009.07.002

De Smet, D., \& Mayer, N. (2016). Integration of it governance and security risk management: A systematic literature review. In Information Society, 2016 International Conference on (pp. 143-148). IEEE. doi:10.1109/iSociety.2016.7854200

Devos, J., Van Landeghem, H., \& Deschoolmeester, D. (2012). Rethinking IT governance for SMEs. Industrial Management \& Data Systems, 112(2), 206-223. doi:10.1108/02635571211204263

Elhasnaoui, Chakir, Chergui, Medromi, \& Moussaid. (2017). Communication System architecture to integrate distributed systems of an IT GRC platform based on agent technology and web services. International Journal of Soft Computing, 12(2).

Elhasnaoui, S., Medromi, H., Faris, S., Iguer, H., \& Sayouti, A. (2014). Designing a Multi Agent System Architecture for IT Governance Platform. International Journal of Advanced Computer Science and Applications IJACSA, 5(5).

Elhasnaoui, S., Moussaid, L., Medromi, H., \& Sayouti, A. (2016). A Communication System Architecture Based on Sharing Information to Integrate Components of Distributed Multi-Agent Systems within an IT GRC Platform. International Journal of Advanced Engineering Research and Science, 3(12).

Gattiker, T. F., \& Goodhue, D. L. (2004). Understanding the local-level costs and benefits of ERP through organizational information processing theory. Information \& Management, 41(4), 431-443. doi:10.1016/ S0378-7206(03)00082-X

Haines \& Goodhue. (2004). Managing Enterprise System Implementations: Key Influences on Enterprise System Module Specialization. Working paper.

Motwani, J., Subramanian, R., \& Gopalakrishna, P. (2010). Critical factors for successful ERP implementation: Exploratory findings from four case studies. Computers in Industry, 56(6), 529-544. doi:10.1016/j. compind.2005.02.005

Nah, F., \& Lau, J. (2001). Critical factors for successful implementation of enterprise systems. Business Process Management Journal, 7(3), 285-296. doi:10.1108/14637150110392782

Nah, F. F.-H., Zuckweiler, K. M., \& Lee-Shang Lau, J. (2003). ERP Implementations: Chief Information Officer's Perceptions of Critical Success Factors. International Journal of Human-Computer Interaction, 16(1), 5-22. doi:10.1207/S15327590IJHC1601_2

Rubino, M., \& Vitolla, F. (2014). Corporate governance and the information system: How a framework for IT governance supports ERM. Corporate Governance, 14(3), 320-338. doi:10.1108/CG-06-2013-0067

Ruivo, P, Oliveira, T, \& Neto, M. (2014). Examine ERP post-implementation stages of use and value: Empirical evidence from Portuguese SMEs. Journal of Accounting Information Systems, 166-184.

Shimizu, K., \& Hitt, M. A. (2004). Strategic flexibility: Organizational preparedness to reverse ineffective strategic decisions. The Academy of Management Executive, 18(4), 44-59. doi:10.5465/ame.2004.15268683 
Tsai, W. H., Chou, Y. W., Leu, J. D., Chen, D. C., \& Tsaur, T. S. (2015). Investigation of the mediating effects of IT governance-value delivery on service quality and ERP performance. Enterprise Information Systems, 9(2), 139-160. doi:10.1080/17517575.2013.804952

Tsai, W. H., Chou, Y. W., Leu, J. D., Chen, D. C., \& Tsaur, T. S. (2015). Investigation of the mediating effects of IT governance-value delivery on service quality and ERP performance. Enterprise Information Systems, 9(2), 139-160. doi:10.1080/17517575.2013.804952

Tsai, W. H., Chou, Y. W., Leu, J. D., Chen, D. C., \& Tsaur, T. S. (2015). Investigation of the mediating effects of IT governance-value delivery on service quality and ERP performance. Enterprise Information Systems, 9(2), 139-160. doi:10.1080/17517575.2013.804952

Turban, E., Leidner, D., Mclean, E., \& Wetherbe, J. (2006). Information Technology for Management: transforming organizations in the digital age (5th ed.). John Willy \& Sons.

Van Grembergen, W., \& De Haes, S. (2005). Measuring and Improving IT Governance through the Balanced Scorecard. Information Systems Control Journal, 2(1), 35-42.

Well, P. (2004). IT governance: how top performers manage IT decision rights for superior result. Harvard Business School Press. 